\title{
Assessment of Risk Factors of Lung Cancer Patients in Babylon Governorate ,Iraq
}

\author{
Ali Abdullah Jasim ${ }^{1}$, Basim Hussein Bahir ${ }^{2}$ \\ ${ }^{1}$ Master Student, Master Of Community Health Technology, College of Health and Medical Technology Baghdad. ${ }^{2}$ \\ PhD Community Medicine, Department of Community Health, College of Health and Medical Technology \\ Baghdad, Middle Technical University, Iraq
}

\begin{abstract}
Background: Lung cancer is one of the most common and serious types of cancer. Cigarette smoking is the main cause of lung cancer.The aims of this study was therefore to assess the risk factors of lung cancer patients in Babylon governorate including tobacco smoking, family history, and occupational exposures, measurement of radon gas in the bed room of patients with lung cancer. Patients and Methods: A case control study was conducted in Babylon oncology center, Murjan medical city during the period from $8^{\text {th }}$ of may to $2^{\text {nd }}$ of september 2019. This center received all lung cancer patients in Babylon governorate. Results: The study showed that $43.3 \%$ of cases were in the age groups 60- 69 years. Males constitute 69.5 $\%$ of cases, seventy one percentage of cases were residing in a rural area. Smoking is the main risk factors of lung cancer in $75.8 \%$, the risk of lung cancer in current smoker is three times more than that of non smoker . Those who had a family history of lung cancer constitute $8.3 \%$,of them $3.9 \%$ were first degree and $4.4 \%$ were second degree ,there was a significant association between lung cancer patients and first degree family history with lung cancer . Those who had a family history of other cancer was $23.6 \%$.The risk factors include radon exposure, asbestose, beryllium,cadmium and diesel exposure were significant associated with lung cancer. The radon value in (77) patients of lung cancer were within exceptable limit.Conclusion : This study revealed that males, age group 60 and above, rural area and smoking is the main risk factors of lung cancer in Babylon city. There is highly significant association between smoking habits and lung cancer cases $\mathrm{p}$-value $<0.05$.
\end{abstract}

Key words: Risk factors, Lung cancer, Radon exposure, Smoking in lung cancer.

\section{Introduction}

Lung cancer is the most common cause of cancer death in men and the second in women after breast cancer ${ }^{1}$. There are two main types of lung cancer smallcell lung carcinoma(SCLC) and non-small-cell lung carcinoma(NSCLC). The most common symptoms are coughing(including coughing up blood),weight loss, shortness of breath, and chest pains ${ }^{2}$.

The risk factors of lung cancer is a multifactorial ,that is many factors work together to cause lung cancer. Globally, risk factors of developing lung cancer include smoking, exposure to radon gas, asbestos, radioactive ores such as uranium, inhaled chemicals or minerals like, beryllium,cadmium, chromium compounds, diesel exhaust, air pollution.Family history of lung cancer increases its risk. The debilitated patients with compromised immune system and elderly over the age of 65 years are more prone to the disease ${ }^{3 \cdot}$. In the USA in 2019 there were about 228,150 new cases of lung cancer 116,440 in men and 111,710 in women , and 142,670 deaths from lung cancer 76,650 in men and 66,020 in women $^{4}$. Each year, more people die of lungcancer than of colon, breast, and prostate cancers combined ${ }^{4}$. The problem of tobacco smoking in Iraq associated with the social and cultural environment, which encourages smoking and influence an individual's attitude toward cigarette smoking ${ }^{\mathbf{5}}$. Tobacco smoking is responsible for the majority of lung cancer cases, cigarette smoking is the cause of approximately $90 \%$ of lung cancer deaths ${ }^{6}$. Another study reported that lung cancer killed approximately $1,590,000$ persons in $2012^{7}$. The primary 
risk factor for lung cancer development and the leading cause of preventable death ${ }^{8}$.

\section{Patients and Methods}

Babylon governorate located in the middle of Iraq is about 100 , kilometers south Baghdad city and has an area of 5,119 Square Kilometers, and population of 1.931 .700 people in 2014 .

A case - control study was conducted on patients attended Murjan medical city, Babylon oncology center throughout the period from $8^{\text {th }}$ of may to $2^{\text {nd }}$ of september 2019 .

Sampling : convenient sample that including all a available patients .

Case: was diagnosed by specialist and referred to the center .

Controls: were age and sex matched .

First degree of family history is defined as a family member who shares about $50 \%$ of their genes with a particular individual in a family, first degree relatives include parents, offspring and siblings ${ }^{9}$.Second degree defined as someone who shares $25 \%$ of persons genes, it includes uncles, aunts, nephews, nieces, grandparents, grandchildren, half- siblings, and double cousins ${ }^{\mathbf{1 0}}$. Current smokers: is ever smokers who are still smoking at the time of the interview ${ }^{\mathbf{1 1}}$.Its including Number of cigarettes smoking per day, and age at beginning of cigarette smoking in years and duration of smoking, number of cigarettes smoking per day ${ }^{\mathbf{1 1}}$.

\section{Data collection technique :}

Data for lung cancer patients risk factors were collected by direct observation using a structured questionnaire after reviewing previous studies.The questionnaire consists of demographic characteristics of patients, risk factors include(smoking, radon ,family history, first degree of family history is defined as a family member who shares about $50 \%$ of their genes with a particular individual in a family, first degree relatives include parents, offspring and siblings ${ }^{9}$.Second degree defined as someone who shares $25 \%$ of persons genes, it includes uncles,aunts,nephews, nieces, grandparents, grandchildren, half- siblings, and double cousins ${ }^{\mathbf{1 0}}$.

Measurement of radon : Radon gas was measured in bed rooms of patients, in cooperation with Babylon environment directorate by using alphaguard professional radon monitor , a modern device used to examine radiation and especially to measure the value of radon gas, normal value of radon is $100 \mathrm{~Bq} / \mathrm{M}^{3}$ according to( WHO $)^{12}$.

\section{Statistical Method}

Data were presented in simple measures of frequency, percentage, mean, standard deviation, and range(minimum- maximum values). The significance of difference of different means (quantitative data), and odd ratio, confidence interval around odd ratio ${ }^{\mathbf{1 3}}$.

\section{Statistical analysis :}

Data analysis was carried out by using the Statistical Package for Social Science (SPSS/ version 25). Finding: A total of 203 cases were include in the study :

Table 1 : Family history of cancer among cases and controls.

\begin{tabular}{|c|c|c|c|c|c|c|c|c|}
\hline \multirow{2}{*}{ Variables } & & \multicolumn{2}{|c|}{ (Cases) } & \multicolumn{2}{|c|}{ Controls } & \multirow{2}{*}{ OR } & \multirow{2}{*}{$\begin{array}{l}95 \% \\
\text { C.I }\end{array}$} & \multirow{2}{*}{ P-value } \\
\hline & & No. & $\%$ & No. & $\%$ & & & \\
\hline \multirow{2}{*}{$\begin{array}{l}\text { Family History of } \\
\text { Lung Cancer }\end{array}$} & First degree & & 3.9 & - & - & 8.69 & $0.08-70.03$ & - \\
\hline & Second degree & 9 & 4.4 & 1 & 0.5 & 9.77 & $1.23-77.89$ & 0.009 \\
\hline
\end{tabular}


Cont... Table 1 : Family history of cancer among cases and controls.

\begin{tabular}{|l|l|l|l|l|l|l|l|l|}
\hline $\begin{array}{l}\text { No family } \\
\text { history }\end{array}$ & & 186 & 91.6 & 202 & 99.5 & Reference & Reference & - \\
\hline \multirow{2}{*}{$\begin{array}{l}\text { Family History of } \\
\text { other Cancer }\end{array}$} & First degree & 8 & 3.9 & 3 & 1.47 & 3.23 & $0.84-12.40$ & 0.071 \\
\cline { 2 - 9 } & Second degree & 40 & 19.7 & 12 & 5.9 & 4.04 & $2.05-7.98$ & 0.0001 \\
\hline No family history & - & 155 & 76.4 & 188 & 92.6 & Reference & Reference & - \\
\hline
\end{tabular}

Table 1 showed that $8.3 \%$ of lung cancer patients had a family history of lung cancer of which first degree were $3.9 \%$, and second degree were $4.4 \%$.The percentage of lung cancer who had a family history of other cancer was $23.6 \%$ of which $3.9 \%$ were first degree and $19.7 \%$ were second degree.

Table 2 : Association of smoking with lung cancer.

\begin{tabular}{|c|c|c|c|c|c|c|c|}
\hline \multirow{2}{*}{ Smoking Habits } & \multicolumn{2}{|c|}{$\begin{array}{l}\text { Lung Cancer } \\
\text { (cases) } 203\end{array}$} & \multicolumn{2}{|c|}{ Controls 203} & \multirow{2}{*}{ OR } & \multirow{2}{*}{ 95\% C.I } & \multirow{2}{*}{ P.value. } \\
\hline & No. & $\%$ & No. & $\%$ & & & \\
\hline Current smoker & 154 & 75.8 & 140 & 69 & 3.07 & $0.65-2.47$ & \multirow{3}{*}{0.496} \\
\hline Passive smoker & 32 & 15.7 & 42 & 20.7 & 0.94 & $0.43-2.07$ & \\
\hline Not smoker & 17 & 8.5 & 21 & 10.3 & Reference & Reference & \\
\hline
\end{tabular}

In table 2 showed that $75.8 \%$ of lung cancer patients were current smoker .The risk of lung cancer in current smoker is 3 times more than in the non smoker.

Table 3 : Association of other risk factors with lung cancer in the studied sample.

\begin{tabular}{|c|c|c|c|c|c|c|c|}
\hline \multirow{2}{*}{$\begin{array}{l}\text { Risk factors and } \\
\text { duration of exposure }\end{array}$} & \multicolumn{2}{|c|}{$\begin{array}{l}\text { Lung cancer } \\
\text { (Cases) } 203\end{array}$} & \multicolumn{2}{|c|}{ Controls 203} & \multirow{2}{*}{ OR } & \multirow{2}{*}{ 95\% C.I } & \multirow{2}{*}{ P-value } \\
\hline & No. & $\%$ & No. & $\%$ & & & \\
\hline Asbestose exposure & 25 & 12.3 & 8 & 3.9 & 3.42 & $1.51-7.79$ & 0.002 \\
\hline Duration (years) & \multicolumn{2}{|c|}{$13.8 \pm 6.9(2-33)$} & \multicolumn{3}{|c|}{$12.6 \pm 2.4(9-17)$} & \multicolumn{2}{|l|}{0.628} \\
\hline Beryllium exposure & 46 & 22.7 & 18 & 8.9 & 3.01 & $1.68-5.41$ & 0.0001 \\
\hline Duration (years) & \multicolumn{2}{|c|}{$16.6 \pm 5.8(7-29)$} & \multicolumn{3}{|c|}{$18.9 \pm 7(11-32)$} & \multicolumn{2}{|l|}{0.177} \\
\hline Cadmium exposure & 11 & 5.4 & 2 & 1 & 5.76 & $1.26-26.32$ & 0.011 \\
\hline Duration (years) & \multicolumn{2}{|c|}{$9.5 \pm 3.4(3-14)$} & \multicolumn{5}{|c|}{$8.5 \pm 4.9(5-12)$} \\
\hline Chromium exposure & 9 & 4.4 & 4 & 2 & 2.31 & $0.70-7.62$ & 0.159 \\
\hline Duration (years) & \multicolumn{2}{|c|}{$12.1 \pm 6.6(5-28)$} & \multicolumn{5}{|c|}{$12.8 \pm 1.3(11-14)$} \\
\hline Diesel exposure & 27 & 13.3 & 7 & 3.4 & 4.30 & $1.83-10.11$ & 0.0001 \\
\hline Duration (years) & \multicolumn{2}{|c|}{$9.8 \pm 5.2(3-27)$} & \multicolumn{3}{|c|}{$7.9 \pm 2.9(4-12)$} & & \\
\hline Others $*$ & $31^{\prime}$ & 15.3 & 26 & 12.8 & 1.23 & $0.70-2.15$ & 0.475 \\
\hline
\end{tabular}

* Others include those who were works in brick factories, spray pesticide and chemicals, exposure to agricultural chemical wastes, individuals that presence in area of asphalt plant and generators worker. 
Table 3: Showed that $(22.7 \%, 13.3 \%, 12.3 \%$ and $5.4 \%)$ were exposed to (beryllium, diesel exhaust ,asbestose and cadmium) respectively, and the association were significant .

Figure 1:This figure showed the radon value in (77) patients of lung cancer. All values of radon were within exceptable limit .The duration of exposure $21.2 \pm 6$ range (5 - 32 ) P.value 0.0001 .

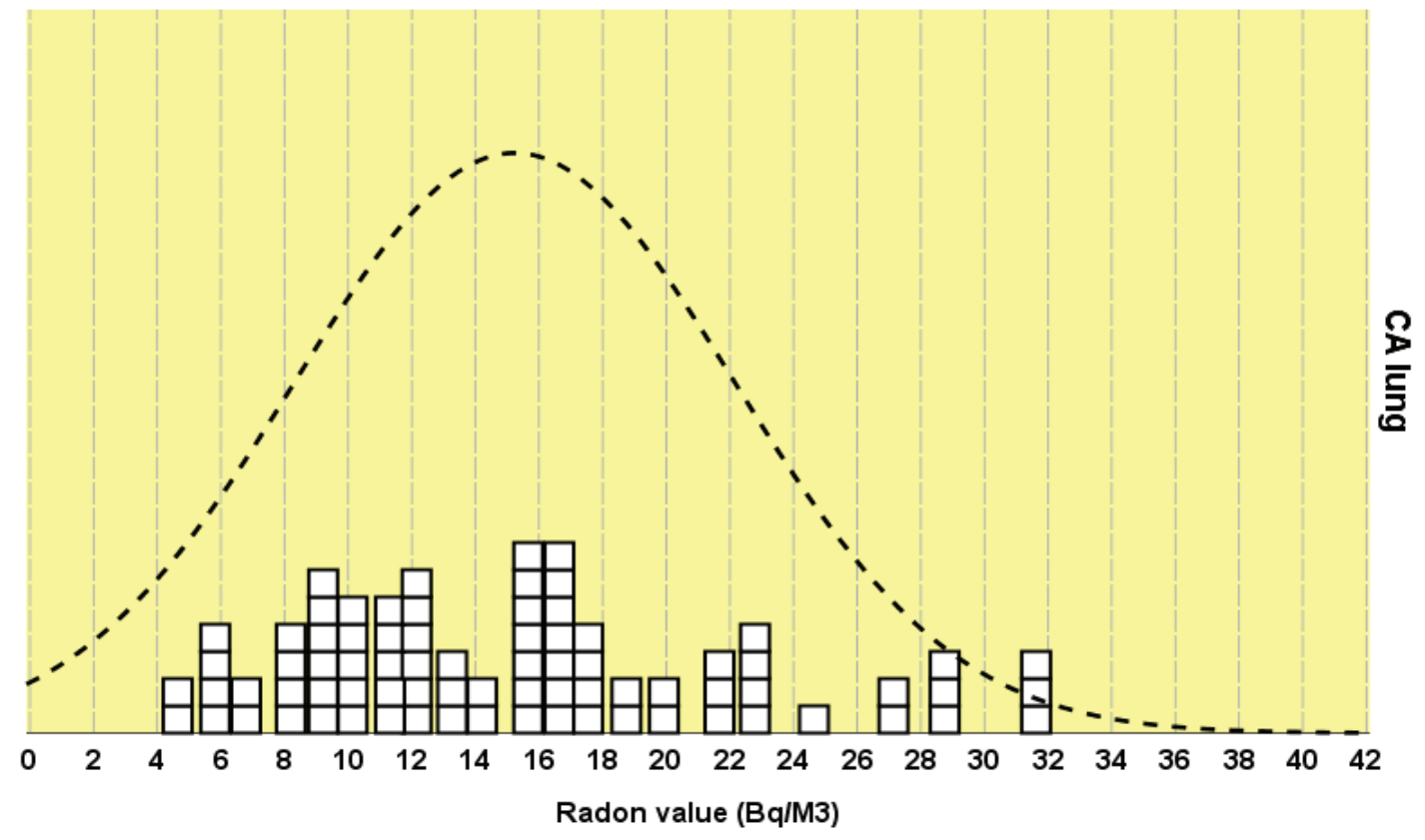

Figure 1 : Distribution of radon value of lung cancer patients .

\section{Discussion}

Regarding the age, the results of this study demonstrated highest percentage ( $43.3 \%$ ) of cases in age group $(60-69)$ years.

Higher percentage of males $69.5 \%$ had lung cancer. This study agrreed with others studies that showed: increase risk of lung cancer in smoking persons more than non-smokers, and in male more than females and in the age groups (50 years and above) ${ }^{\mathbf{1 4 , 1 5}}$ . This may be due to higher percentage of smoking in males, passive smoking, type of occupational exposure and other risk factors are more in the males than in the females. This study demonstrated the risk of lung cancer in the current smoker were three times more than non smokers, which was supported by other studies, that indicated that cigarette smoking plays an important risk factor in the occurrence of lung cancer ${ }^{\mathbf{1 6}}$. The current study revealed that $71.4 \%$ of cases were living in rural area, which agreed with the study of Stamm et al.,2007, which found that lung cancer was more in rural area than in urban area.$^{17}$

This showed that the $22.7 \%, 13.3 \%$, and $12.3 \%$, there was a significant between lung cancer and exposed to beryllium, diesel exhaust and asbestose. The results agreed with others studies. These studies found that occupational exposure including radon exposure, and asbestos, beryllium, cadmium, chromium, diesel exhaust are constitutes a leading risk factors for lung cancer according to the type of occupation ${ }^{18,19}$. There was a significant association between lung cancer patients and first degree family history lung cancer .Lung cancer patients had 8.7 times more family history of first degree patients with lung cancer. That was in agreement with a study that found brothers, sisters, and children of people who have had lung cancer may have a slightly higher risk of lung cancer themselves, especially if the relative was diagnosed at a younger age. It's not clear how much of this risk might be due to shared genes among family members. ${ }^{20}$. 
There were many limitations for this study . Firstly : The sample was convenient which included all available cases at the time of the study, so we not able to include all cases .

Secondly : Measurement of radon was done for (77) patients only, which not reflect the total exposure for all patients. This because there was only one radon gas measurement device available in the directorate of environment of Babylon, and the far distance between houses of patients .

\section{Conclusion}

This study revealed that males, age group 60 and above, rural area and smoking is the main risk factors of lung cancer in Babylon city .There is highly significant association between smoking habits and lung cancer cases $\mathrm{p}$-value $<0.05$.

\section{Conflict of Interest : none}

\section{Source of Funding : self}

Ethical Clearance : From patients and babel health directorate and my college .

\section{References}

1. Murtaza et al., Lung Cancer: Risk Factors, Management, And Prognosis .e-ISSN: 2279-0853, p-ISSN: 2279-086 1. 2016,15 (10) , PP 94-101.

2. Falk S, Williams C . "Chapter 1". Lung Cancerthe facts (3rd ed.). Oxford University Press. pp. 3-4. ISBN .2010 , 978-0-19-956933-5.

3. Zhong, L.; et al Exposure to environmental tobacco smoke and the risk of lung cancer: A meta-analysis. Lung Cancer; 2000, 27 : 3-18.

4. DeSantis CE, Miller KD, Sauer AG, et al,. Cancer statistics for African Americans, 2019. CA: A Cancer Journal for Clinicians. 2019; 69:211-233.

5. Mousawi AA. The prevalence of smoking among Karbala/Iraq universitystudents in Iraq in 2005. Tob Use Insights (2014) 10:7:9-14.

6. Tu CY, Cheng FJ, Chen CM, et al., Cigarette smoke enhances oncogene addiction to c-MET and desensitizes EGFR-expressing non-small cell lung cancer to EGFR TKIs. Mol Oncol. (2018)12:70523.
7. Islami E, Torre LA, Jemal A. Global trends of lung cancer mortality and smoking prevalence. Transl Lung Cancer Res. (2015) 4:327-38.

8. Stewart SL, et al., Surveillance for cancers associated with tobacco use-United States, 19992004. MMWR Surveill Summ 2008;57: 1-33.

9. Ginsburg \& Geoffrey; genomic and personalized medicine ; 2008, volumes 1-2. P. 482. Wiki < https : // en.m. Wikipedia. Org .

10. Blue cross \&Blue shield ; First \&second\& third degree relative ; 2008, volumes 1-2. P. 482. Wiki< https : // en.m. Wikipedia.Org .

11. He Y, Lam TH, Jiang B, et al., Combined Effects of Tobacco Smoke Exposure and Metabolic Syndrome on Cardiovascular Risk in Older Residents of China. Journal of the American College of Radiology . 2009; 53: 363 - 371.

12. World Health Organization,https:// www.who.int/ whosis/whostat/en/2009.

13. Biostatistics : A Foundation for Analysis in the Health Sciences. Wayne W Daniel \&Chad L Cross; $10^{\text {th }}$ ed.. John Wiley \& Sons Inc, USA, 2013.

14. Koo LC, Ho JH-C. World wide epidemiological patterns of lung cancer in non-smokers.Int $\mathrm{J}$ Epidemiol 1990 ; 19 (Suppl 1): S14 -S23. Google Scholar.

15. Jemal A, Bray F, Center MM, Ferlay J, et al, (February 2011). "Global cancer statistics". Ca. 61 (2): 69-90.

16. Parkin DM. Tobacco-attributable cancer burden in the UK in 2010. Br J Cancer 2011;105 (Suppl 2):S6-S13

17. Stamm B.H., Lambert D., Piland N.F. A rural perspective on health care for the whole person. Prof. Psychol. Res. Pract. 2007;38:298.

18. Couraud S, Zalcman G, Milleron B, et al., Lung cancer in never smokers-a review. Eur J Cancer 2012; 48: 1299-1311.

19. Torres-Durán M, Ruano-Ravina A, ParenteLamelas I, et al., .Lung cancer in never-smokers: a case-control study in a radon-prone area (Galicia, Spain). EurRespir J 2014; 44: 994-1001 .

20. Varella-Garcia M. Chromosomal and genomic changes in lung cancer. Cell Adh Migr.2010;4(1):100-106. 